\title{
RESEARCH ON UNDERGROUND WATER QUALITY FROM ALMAȘU MARE AREA
}

\author{
Adriana $B \breve{A B} \breve{A} U^{1}$, V. MICLE ${ }^{1}$, I. M. SUR ${ }^{1}$
}

\begin{abstract}
Research on underground water quality from Almașu Mare area. Environmental contamination with heavy metals is one of the major problems all over the world. In most cases the heavy metals are presents in the environment as a consequence of human activities. Romania is known for intense mining activities for centuries. The impact of nonferrous metal extraction from underground caused a major imbalance on the environment such as: residual water, destruction of soil quality, fertile soil layer, agricultural terrains and changes in the flow groundwater, air pollution and mine wastes with a negative effect on the environmental and human health. Past mining activities represents a negative impact on the environment, due to continuous leakages of mine and large quantities of waste deposited. In Almașu Mare mining area, the exploitation activity has a long history with a important impact on water pollution. Water pollution with heavy metals in Almașu Mare area is mainly due to leakages of mine. Haneș mine from Almașu Mare is a significant problem, representing a serious risk to human health and the environment. These issues require effective solutions, but at a reduced cost. The study consists in water quality assessment in the Haneș mine area and proposing optimal solution for remediation and stabilization of the situation in the studied area. Water quality assessment consists in the determination of the heavy metals concentration from underground water and to compare analyses results to the admissible limits concentration regarding the content of the heavy metals in the surface waters.
\end{abstract}

Keywords: undergound water, Almașu Mare, mining activities, Haneș mine, heavy metals.

\section{INTRODUCTION}

Water is one of the essentials for plant, animal and human life (Awomeso et al., 2010). One of the most important environmental issues today is water contaminated with heavy metals because of strong toxicity at low concentrations (Marcovecchio et al., 2007). The build-up of metals in sediments has significant environmental implications for local communities, as well as for river water quality. For example, many freshwater invertebrates process sediment as a food source and can be susceptible to bioaccumulation of toxic metals (Ahmet and al., 2006) . This bioaccumulation can potentially threaten the health of many species at the top of the food chain, especially birds, fish and humans (Wright and Mason, 1999). Heavy metals have the ability to persist in natural ecosystems for an

\footnotetext{
${ }^{1}$ Technical University, Faculty of Materials and Environmental Engineering, 400641, Cluj-Napoca, Romania, e-mail: adriana.babau@yahoo.com
} 
extended period (Nomanbhay and Palanisamy, 2005; Berar and el., 2011). Recent, environmental pollution has increasingly gained a global interest (Ayantobo and al., 2014). The main source of contamination of the environment is industry, the mining activities that pollute the environment are: extraction and preparation, which contributes to emissaries polluted with toxic substances (Cosma, 2012). Contamination of surface in gold mining communities is a serious environmental problem in many countries from worldwide (Aslibekian and Moles, 2003). In the Apuseni Mountains area from Romania, mining activities have taken place since antiquity, leaving their marks upon the environment, the aquatic one inclusively. It is about the disorganization of the hydrographical basins and especially about aggressive pollution of surface waters with some of the most toxic chemical substances such as cyanides, as well as by an increase in the contents of metallic ions, chlorides, sulphides, sulphates, suspensions and fixed residuum. The decrease in $\mathrm{pH}$, and implicitly the acidification of waters, is also remarkable (Duma, 2012). This study was performed in accordance with the directive 60/2000/EC of the European Parliament and of the Council which seeks to establish a framework for the improvement of aquatic ecosystem through specific measures for reducing or stopping emissions loaded with dangerous substances. The study was to assess undeground water quality by determining the physical-chemical parameters.

\section{MATERIALS AND METHODS}

\subsection{The study Area}

Almaşu Mare is located on the southern outskirts of the Apuseni Mountains from Romania (Fig. 1.), in the subunit of Metaliferi mountains, bordering the town Zlatna, Alba county and city Geoagiu. Occupying a total area of 9330 ha. Since 1900, in Almașu Mare were performed mining activities.

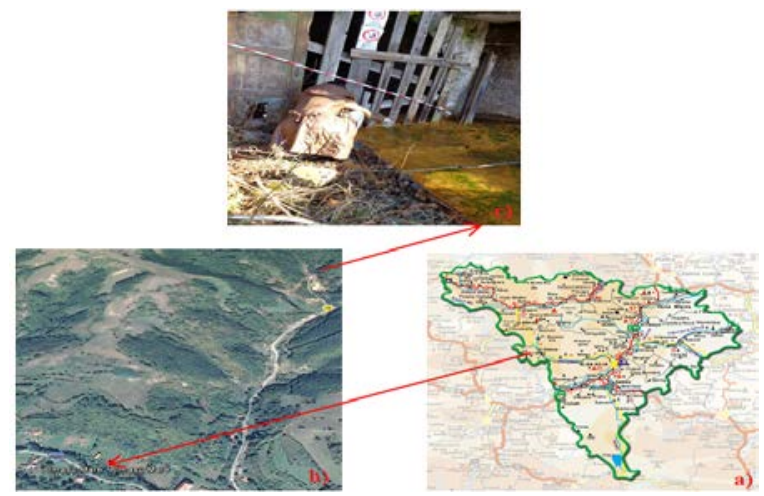

Fig. 1. The map of the study: a-Alba county, $b$ - Almașu Mare village, $c$ - Haneș mine.

Water sample was taken from the Haneș mine entrance, on November 19, 2016. Haneş mine is located at a distance of $18 \mathrm{~km}$ from the copper plant from Zlatna, it is located at an altitude of approximately $700 \mathrm{~m}$, in the Almaşu Mare 
village (Stancu, 2013). Therefore, on this territory there are three galleries of mine, such as: All Saints gallery, Radeș gallery and Haneș gallery. The water of Haneș mine flow into the Almaș Valley (tributary of the Geoagiu River) with a discharge of $600 \mathrm{~m}^{3} /$ day. The mine water quality is affected by the presence of great quantities of metallic ions (Cu, Pb, Zn, etc.) and by a very acid pH (Duma, 2012).

\subsection{Underground water quality assessment}

The assessment of underground water quality consisted in the physicochemical parameters determination of water sample taken from the Haneș mine entrance. Harvesting of water sample was done in a polyethylene bottle with glass stopper fitted with hermetic close. The next day sample water was brought to the laboratory of the Technical University from Cluj Napoca, in refrigerator for several hours. In order to analysis the heavy metals concentrations $(\mathrm{Cu}, \mathrm{Zn}$ and $\mathrm{Pb})$ from water sample that was diluted and then analyzed with Shimadzu atomic absorption spectrophotometer AA-6800. Other parameters analyzed in order to determine surface water quality in the study area were: $\mathrm{pH}$, conductivity and dissolved oxygen. The $\mathrm{pH}$, conductivity and dissolved oxygen were analyzed by WTW 2FD47F Multi 3430 Multiparameter Meter.

Also, in 2008, Hulpoi has conducted research on water quality in the Haneș mine area. Water sample was taken from the mine entrance. Surface water quality research was to determine the $\mathrm{pH}$ value and the heavy metals concentrations in water. For the determination of the heavy metals concentrations this researcher, Hulpoi, used X-ray fluorescence spectrophotometer. Table 1 summarize the features of spectrometric analysis methods used to determine the heavy metals concentrations from the groundwater samples.

Table 1. Features of the usual analytical methods used in order to determine heavy metals concentrations (Popa M., 2008).

\begin{tabular}{|ll|}
\hline Atomic absorption & The sample is aspirated into the flame \\
spectrometry & Sample sizes between $25 \mathrm{mg}$ and $1 \mathrm{~g}$ \\
& Allows analysis of the order $\mathrm{mg}$, or ng per milliliter of solution. \\
& Heavy metals are determined individually \\
& Data can be obtained with accuracy only for individual determinations \\
X-ray fluorescence & The sample irradiated with a light beam \\
spectrometer (X-ray & Requires no sample preparation \\
Fluorescence) & Allows the determination of the elements of atomic number Z = 5 (B) \\
& to Z $=92$ (U) \\
& Screening for multiple items \\
& Can accept only small samples \\
& For precision and accuracy test will be toughened \\
& (Monolayer) \\
& Sensitive to many factors
\end{tabular}

As to the performance of analysis methods in order to determine heavy metals concentrations is considered that the atomic absorption spectrometry is more accurate than x-ray fluorescence spectrometry. In order to establish the 
underground water quality degree from Almașu Mare area, in the following are present the results of surface water analysis, in 2016, but also those obtained by Hulpoi researcher in 2008.

\section{RESULTS AND DISCUSSION}

The $\mathrm{pH}$ measured in water samples taken both in 2008 and in 2016 at the Haneș mine entrance, gives the general indication that the water is very acidic (Fig. 2). The value of electrical conductivity measured in 2016, in water sample was 3.6 $\mu \mathrm{S} / \mathrm{cm}$ and dissolved oxygen $6.5 \mathrm{mg} / \mathrm{l}$.

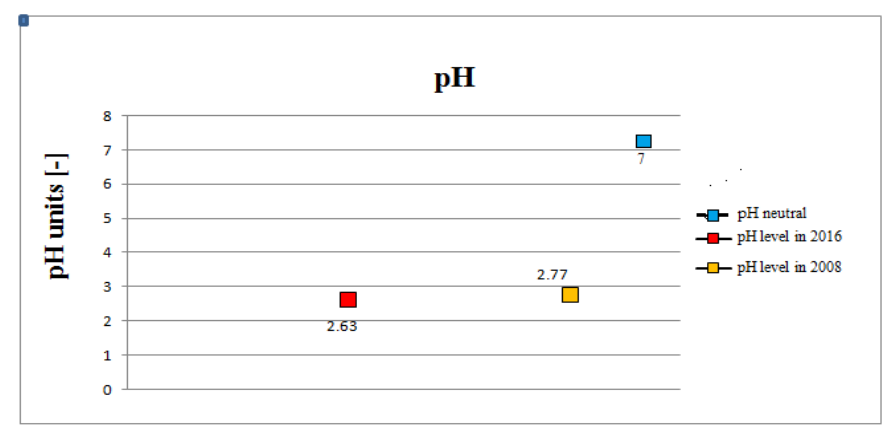

Fig. 2. The $\mathrm{pH}$ values in underground water samples.

The $\mathrm{pH}$ value was 2.63 in 2016, and in 2008 being 2.77, which results a slight decrease of the $\mathrm{pH}$ in the years 2008-2016. Neutral $\mathrm{pH}$ falls within the range 6.5-8.5 provided in NTPA-001/2002 normative.

In figure 3 is highlighted the concentration of zinc ions in 2008 and 2016.

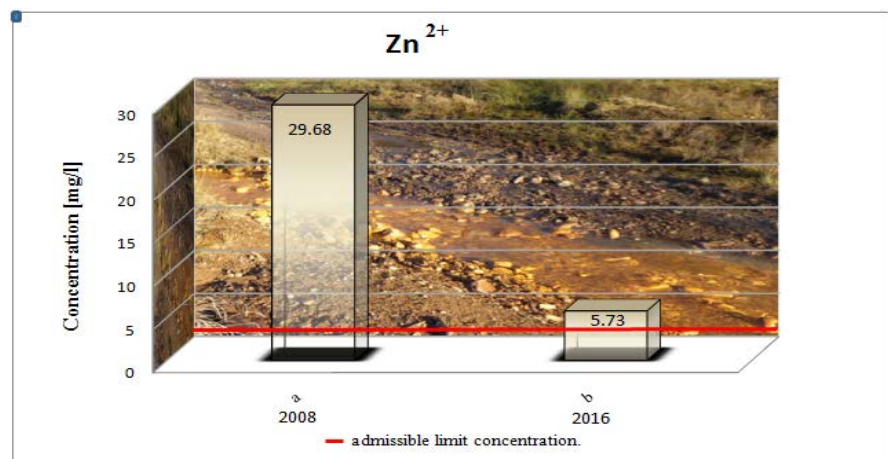

Fig. 3. The concentration of zinc ions found in following the analysis performed on water samples taken from the Haneş mine entrance.

After obtaining the analysis results of water sample taken from the Hanes mine entrance was highlighted a high content of zinc in $2008(29.68 \mathrm{mg} / \mathrm{l})$ and the lowest in $2016(5.73 \mathrm{mg} / \mathrm{l})$. Both values of zinc exceed the allowed limit of 0.5 $\mathrm{mg} / \mathrm{l}$ which is provided in NTPA-001/2002 normative. Lead was below the 
detection limit of the atomic absorption spectrophotometer AA-6800 and of the Xray fluorescence spectrophotometer. In figure 4 is highlighted the concentration of copper ions in 2008 and 2016.

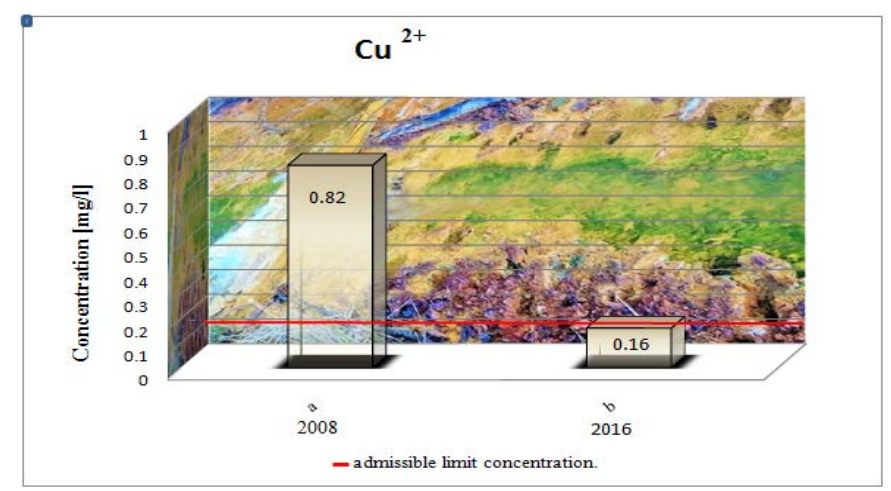

Fig. 4. The concentration of copper ions found in following the analysis performed on water samples taken from the Haneş mine entrance.

Referring to copper ions found in water samples taken in 2008 and 2016 there is a decrease them. The concentration of copper ions found in 2008 is 0.82 $\mathrm{mg} / \mathrm{l}$, and in 2016 is $0.16 \mathrm{mg} / \mathrm{l}$. Also, both values of copper exceed the allowed limit of $0.1 \mathrm{mg} / \mathrm{l}$ which is provided in NTPA-001/2002 normative.

\section{CONCLUSIONS}

The $\mathrm{pH}$ of underground waters in the studied area indicate a value of 2.63 in 2016, and in 2008 a value of 2.77, which indicates the acidic conditions in the studied area. This acidic medium favor the dissolution of minerals and transition in solution of heavy metals metal ions. The acidity of the water from the Haneş mine and the content of heavy metals in it presents a risk to human communities and/or natural ecosystems (soil, water resources, flora, fauna) in the area, whereas the permissible limit values are exceeded over 10 times in the case of zinc ions and copper ions a little over. The lead concentration was below the detection limit of the spectrophotometer. Decreasing the content of zinc ions in 2016 compared to 2008 may be due to the fact that, over the years ( 8 years) the zinc was washed by the passage continues water through gallery of mine. Therefore although any mining activity in the Almașu Mare area was closed the pollution remains because of poorly made mine closures.

After performing regarding physico-chemical water analysis has shown that the water drains from the Haneș mine may have a potential negative impact on underground and surface waters, which is an argument in order to close the mines in the Almașu Mare area (All Saints mine, Radeș mine and Haneș mine) properly and apply methods for remediation of environmental quality in this mining area. 


\section{ACKNOWLEDGEMENTS}

This work was supported by a grant of the Romanian National Authority for Scientific Research, CNCS - UEFISCDI, project number PN-II-PT-PCCA2013-4-1717.

\section{REFERENCES}

1. Aslibekian, O. and Moles R. (2003), Environmental risk assessment of metals contaminated soils at silver mines abandoned mine site, co tipperary, Ireland. Environ. Geochem. Health, 25: 247-266. DOI: 10.1023/A:1023251102402;

2. Ayantobo, O.O., Awomeso J.A., Oluwasanya G.O., Bada B.S. and Taiwo A.M. (2014), Gold mining in igun-ijesha, southwest nigeria: Impacts and implications for water quality, American Journal of Environmental Sciences 10 (3): 289-300;

3. Berar I.M., Micle V., Urs A.M., (2011), Research on Contaminated Soils from Baia Mare Area and their Remediation by In Situ Bio-Leaching Technique, ProEnvironment 4(2011) 208 - 211;

4. Cosma F.C. (2012), Study regarding utilization of biological filters for the mining wastewater treatment from apuseni mountains area, Pangeea;

5. Demirak A., Yilmaz F., Tuna L. and Ozdemir N. (2006), Heavy metals in water, sediment and tissues of Leuciscus cephalus from a stream in southwestern Turkey, Chemosphere 63 (2006) 1451-1458;

6. Duma S. (2012), The impact of mining activity upon the aquatic environment In the southern apuseni mountains, Romanian review of regional studies, Vol 1;

7. Hulpoi A. A. (2008), Characterization of sources of pollution in the Zlatna-Hanes mining area, National Student Symposium GEOECOLOGY IX;

8. Marcovecchio, J.E., Botte S.E. and Freije R.H. (2007), Heavy Metals, Major Metals, Trace Elements. In: Handbook of Water Analysis, L.M. Nollet (Ed.), CRC Press, London, ISBN-10: 1420006312, pp: 275-311;

9. Nomanbhay, S.M. and Palanisamy K. (2005), Removal of heavy metal from industrial wastewater using chitosan coated oil palm shell charcoal. Elec. J. Biotechnol;

10. Popa M. (2008), Metode de analiză utilizate în determinarea contaminării cu metale grele, Pangeea;

11. Stancu P.T. (2013), PhD thesis entitled: "Studies geochemical and mineralogical changes resulting from secondary processes of mining and remediation technologies areas polluted with heavy metals and / or rare in the Zlatna, Faculty of Geology and Geophysics, Bucharest;

12. Wright, P., Mason, C.F., (1999), Spatial and seasonal variation in heavy metals in the sediments and biota of two adjacent estuaries, the Orwell and the Stour, in eastern England. Sci. Total Environ. 226, 139-156;

13. *** (2000), 60/2000/EC of the European Parliament and of the Council of 23 Oct. 2000 establishing a framework for Community action in the field of water policy;

14. *** (2002), Normative of 28 February 2002 on the establishment limits of charging with pollutants of industrial and urban sewage discharge into natural receivers, NTPA-001/2002 Published in the Official Gazette, Part I no. 187 of 20 March 2002. 